\title{
HPLC method validation for quantification of tetrahydrocurcumin in bulk drug and formulation
}

\author{
Roopam Raut ${ }^{*}$ (D) and Jessy Shaji
}

\begin{abstract}
Background: Tetrahydrocurcumin (THC), the active metabolite of curcumin, is gaining popularity amongst scientist due to its wide spectrum of pharmacological activities, better stability and colourless nature. The objective of this study was to develop a sensitive, cost-effective RP-HPLC method for the estimation of THC in bulk drug substance and formulation.

Results: Efficient chromatographic separation was achieved on Hypersil BDS, C18 column, $250 \mathrm{~mm} \times 4.6 \mathrm{~mm}, 5 \mu \mathrm{m}$ column by isocratic elution with mobile phase comprising of acetonitrile: methanol: water (40:23:37\% VM); adjusted to a pH of $3.0 \pm 0.05$. The flow rate of the mobile phase was $1.0 \mathrm{ml} / \mathrm{min}$ with a column temperature of $25^{\circ} \mathrm{C}$. UV detector was used for the analysis and detection was carried out at $280 \mathrm{~nm}$. The developed method was validated according to ICH guidelines with respect to system suitability, linearity, accuracy, precision and robustness. The theoretical plates were found to be more than 5800. The method showed linearity over the range of 4 to $60 \mu \mathrm{g} / \mathrm{ml}$ with $R^{2}=0.9998$. The accuracy of the method in terms of recovery study was $98.23-99.99 \%$. The \%RSD for intra-day and inter-day precision were 0.272 and 0.275 , respectively. The method was found to be robust with respect to change in wavelength, flow rate and column temperature.
\end{abstract}

Conclusion: The analytical method was found satisfactory on validation as per ICH guidelines. Hence, it can be routinely used for quantification of THC in bulk drug and formulation.

Keywords: Tetrahydrocurcumin, HPLC-UV, Quantification, Method validation

\section{Background}

Curcumin is a principal bioactive component of plant Curcuma longa (Linn). It is a potent antioxidant exhibiting various pharmacological activities [1]. Tetrahydocurcumin (THC) is an active metabolite of it [2] where both the double bonds are reduced to single bonds (Fig. 1). Chemically, it is 1,7-bis(4-hydroxy-3-methoxyphenyl)heptane-3,5-dione with empirical formula $\mathrm{C}_{21} \mathrm{H}_{24} \mathrm{O}_{6}$ and molecular weight 372.4. THC retains a range of therapeutic properties. It has been shown to ameliorate oxidative stress-induced renal injury [3] and was able to mitigate mitochondrial dysfunction in brain vasculature

\footnotetext{
* Correspondence: roopam4pharma@gmail.com

Principal K. M. Kundnani College of Pharmacy, Rambhau Salgaonkar Marg, Mumbai 400005, India
}

\section{Springer Open}

(0) The Author(s). 2021 Open Access This article is licensed under a Creative Commons Attribution 4.0 International License, which permits use, sharing, adaptation, distribution and reproduction in any medium or format, as long as you give appropriate credit to the original author(s) and the source, provide a link to the Creative Commons licence, and indicate if changes were made. The images or other third party material in this article are included in the article's Creative Commons licence, unless indicated otherwise in a credit line to the material. If material is not included in the article's Creative Commons licence and your intended use is not permitted by statutory regulation or exceeds the permitted use, you will need to obtain permission directly from the copyright holder. To view a copy of this licence, visit http://creativecommons.org/licenses/by/4.0/. antiparkinson activity [6] and anticancer activities [7].

Excellent pharmacological effects with added advantage of colourless nature has made scientist to take note of THC. Different dosage forms like cream [8], porous scaffold for cartilage regeneration [9], self-emulsifying floating drug delivery systems [10] have been developed across the globe.

Various analytical methods HPLC, UHPLC, LC-MS/ MS etc. have been developed for identification of metabolites of curcumin. THC being one of the metabolite of curcumin has been identified in biological samples like plasma and urine [11-13]. But reference for a simple reliable HPLC method for estimation of THC in the formulation is not available. In the present study, HPLC 
based analytical method has been developed and validated for quantitative determination of THC in the gel formulation.

\section{Methods}

Chemicals and reagents

All the solvents were of analytical grade and purchased from Qualigens (Thermo Fisher Scientific). Purified water was purchased from JK labs (Mumbai). The tetrahydrocurcumin (Sabiwhite) was obtained from Sami Labs, Bengaluru, Karnataka, India.

\section{Method development}

\section{Preparation of standard solution}

Ten milligrams of tetrahydrocurcumin was accurately weighed and transferred to a $50 \mathrm{ml}$ volumetric flask. Thirty-five milliliters of methanol was added and with the aid of sonication, it was dissolved completely. Volume was made up and solution was mixed well. Ten milliliters of aliquot was withdrawn and diluted to $50 \mathrm{ml}$ with diluent.

\section{Preparation of sample solution}

Five hundred milligrams of the $1 \% \mathrm{w} / \mathrm{w}$ tetrahydrocurcumin gel was weighed on a butter paper and transferred the gel along with butter paper to a $50 \mathrm{ml}$ beaker containing $25 \mathrm{ml}$ of diluent. The sample was sonicated for 5 min to form clear solution and the contents of the beaker were transferred to a $50 \mathrm{ml}$ volumetric flask. The beaker was rinsed 2 times by $10 \mathrm{ml}$ of methanol and transferred the same to the volumetric flask. The volume was made up to the mark with diluent and mixed well. The solution was filtered through a $0.45 \mu \mathrm{m}$ Nylon syringe filter discarding 3-5 ml of sample. Ten milliliters aliquot was further diluted with methanol to $25 \mathrm{ml}$.

\section{Chromatographic conditions}

The system comprised of a Jasco PU-2089 HPLC Pump equipped with Jasco-2070 UV/Vis detector. The Mobile phase composed of acetonitrile: methanol: water (40:23: $37 \% \mathrm{~V} / \mathrm{V}$ ); adjusted to a $\mathrm{pH}$ of $3.0 \pm 0.05$ was used for the study. The mobile phase was filtered through a $0.45 \mu \mathrm{m}$ pore size membrane PVDF filter and degassed ultrasonically after mixing. Twenty microliters of the solution was injected. The flow rate was maintained at 1 $\mathrm{ml} / \mathrm{min}$. The column used for the study was Hypersil<smiles>COc1cc(CCC(=O)CC(=O)CCc2ccc(O)c(OC)c2)ccc1O</smiles>

Fig. 1 Tetrahydocurcumin structure
Table 1 System suitability study

\begin{tabular}{lllll}
\hline $\begin{array}{l}\text { Injection } \\
\text { time }\end{array}$ & $\begin{array}{l}\text { Retention } \\
\text { Peak area }\end{array}$ & $\begin{array}{l}\text { Asymmetry } \\
\text { factor }\end{array}$ & $\begin{array}{l}\text { Theoretical } \\
\text { plates }\end{array}$ \\
\hline 1 & 6.62 & 19186889 & 1.16 & 5943 \\
2 & 6.62 & 19126526 & 1.15 & 5997 \\
3 & 6.62 & 19234275 & 1.15 & 5985 \\
4 & 6.62 & 19198526 & 1.15 & 5973 \\
5 & 6.63 & 19183676 & 1.15 & 5956 \\
6 & 6.63 & 19196342 & 1.16 & 5883 \\
Mean & $\mathbf{6 . 6 2 3}$ & $\mathbf{1 9 1 8 7 7 0 5 . 6 7}$ & $\mathbf{1 . 1 5 3}$ & $\mathbf{5 9 5 6 . 1 7}$ \\
SD & $\mathbf{0 . 0 0 5}$ & $\mathbf{3 4 9 8 6 . 3 6}$ & $\mathbf{0 . 0 0 5}$ & $\mathbf{4 0 . 7 6}$ \\
\%RSD & $\mathbf{0 . 0 7 8}$ & $\mathbf{0 . 1 8}$ & $\mathbf{0 . 4 4 8}$ & $\mathbf{0 . 6 8}$ \\
\hline
\end{tabular}

BDS, C18 column, $250 \mathrm{~mm} \times 4.6 \mathrm{~mm}, 5 \mu \mathrm{m}$. The column oven temp was maintained at $25^{\circ} \mathrm{C}$. The detection was carried out at wavelength $280 \mathrm{~nm}$. The run time for the analysis was $10 \mathrm{~min}$.

Validation of method: quantitation of THC in bulk and pharmaceutical dosage form

The developed method was validated for system suitability, accuracy, precision, linearity and robustness in accordance with $\mathrm{ICH}$ guideline for validation of analytical procedures Q2(R1).

\section{System suitability}

System suitability testing helps to decide whether the developed chromatographic system is suitable for the analysis. \%RSD of retention times, asymmetry factors and theoretical plates were the parameters for the study. Six replicate samples containing tetrahydocurcumin were analyzed using the developed method.

Filter study is carried out to ensure that no drug is retained by the filter during sample preparation. The solution was collected after passing through a $0.45 \mu \mathrm{m}$ PVDF filter and a $0.45 \mu \mathrm{m}$ Nylon filter, by discarding 5 $\mathrm{ml}$ of solution. The results were compared to unfiltered centrifuged sample solution.

\section{Specificity}

The mobile phase or the excipients in the formulation should not interfere with the analysis. The developed method needs to be specific. The blank, placebo solution, THC solution and gel solution were injected and peak purity was determined.

Table 2 Filter study

\begin{tabular}{ll}
\hline Sample & \% Absolute difference \\
\hline $\mathbf{0 . 4 5} \boldsymbol{\mu m}$ PVDF filter & 0.10 \\
$\mathbf{0 . 4 5} \boldsymbol{\mu m}$ Nylon filter & 0.08 \\
\hline
\end{tabular}



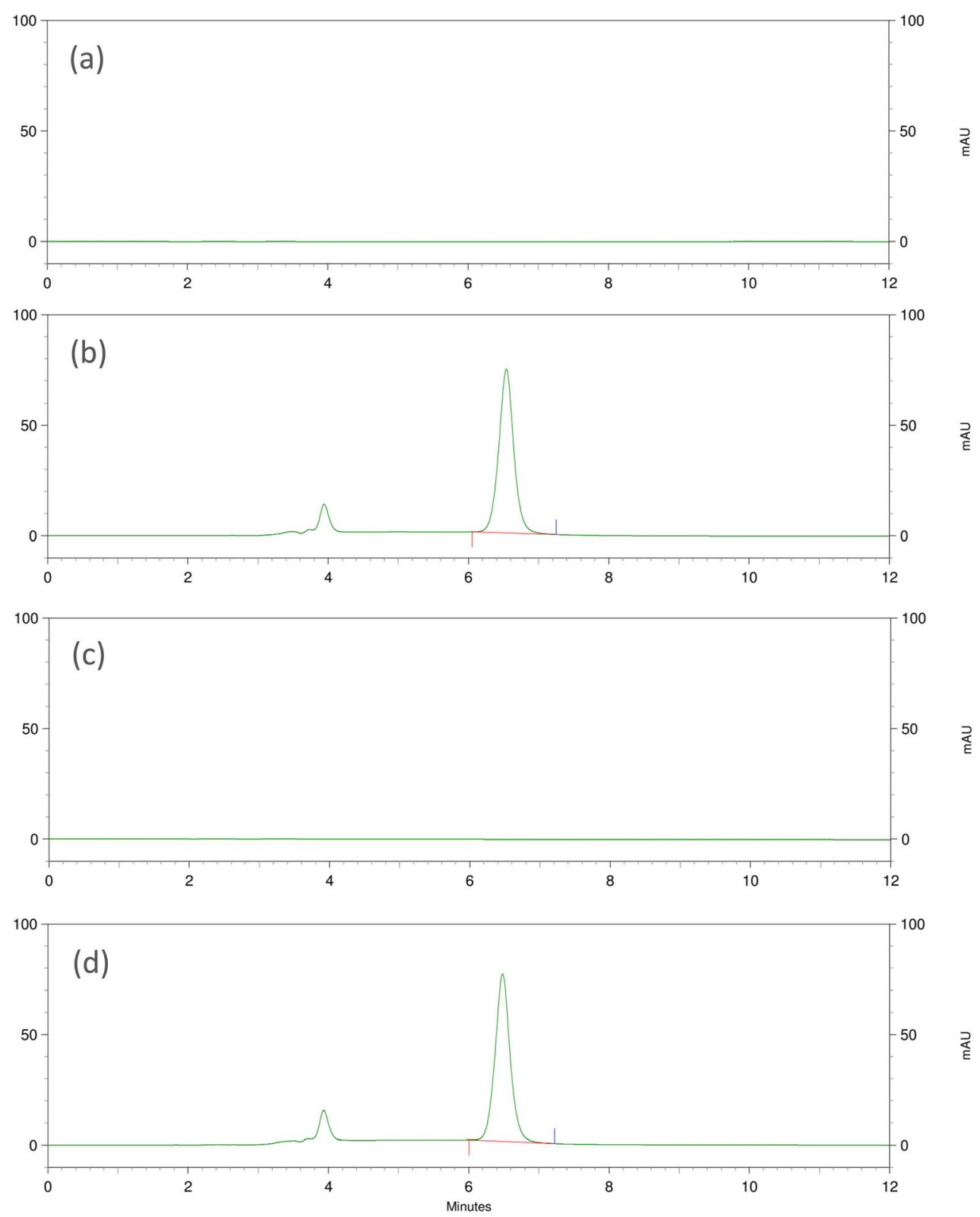

Fig. 2 Chromatograms of (a) blank (b) tetrahydrocurcumin standard (c) placebo (d) tetrahydrocurcumin sample

\section{Linearity}

THC solutions at 5 levels were prepared from 10 to $150 \%$ of working concentration. At each level, analysis was carried out in triplicate. The peak areas versus concentrations data was evaluated by linear regression analysis. Three data set corresponding to triplicate analysis were constructed. This data was analyzed by the test one-way ANOVA with post test Tukey using a significant level of $\alpha=0.05$ (95\% of confidence interval).

\section{Accuracy}

An accuracy study was performed by adding known amounts of THC to the placebo preparation. The actual and measured concentrations were compared and recovery was calculated. Recovery of the method was evaluated at three different concentration levels (corresponding to 50,100 and $150 \%$ of test preparation concentration). For each concentration level, three sets were prepared and measured.

\section{Precision}

The precision of the assay method was evaluated in terms of repeatability by performing six independent assays (intra-day) of THC. Under the same experimental conditions, intermediate precision of the method was checked by another person performing the same 
Table 3 Specificity study

\begin{tabular}{ll}
\hline Blank & $\begin{array}{l}\text { No interference at RT of Tetrahydrocurcumin in } \\
\text { blank }\end{array}$ \\
$\begin{array}{ll}\text { Standard } \\
\text { solution }\end{array}$ & Peak purity was 0.997 \\
Placebo & $\begin{array}{l}\text { No interference at RT of Tetrahydrocurcumin in } \\
\text { placebo }\end{array}$ \\
Sample solution & Peak purity was 0.996
\end{tabular}

procedure on a different day (inter-day). \%RSD not more than 2 was taken as the limit.

\section{Robustness}

The factors chosen for this study were the change in wavelength $(+,-3 \mathrm{~nm})$, flow rate $(+,-10 \%)$ and column temperature $\left(+,-2{ }^{\circ} \mathrm{C}\right)$. The appropriate amounts of THC, bulk drug and formulation were weighed and diluted with methanol. The effect of changed parameters on analysis of THC in bulk drug was evaluated in terms of RT, asymmetry factor, theoretical plates and assay.

\section{Results}

\section{System suitability}

In system suitability study, the peak showed good symmetry (average 1.15) and sufficient theoretical plates (average 5956). The average retention time was $6.62 \mathrm{~min}$. $\%$ RSD of retention times, asymmetry factors and theoretical plates was well below 1\% (Table 1). PVDF and nylon both filters were found to be suitable as maximum $\%$ absolute difference was $0.10 \%$ (Table 2 ).

\section{Specificity}

The method proved to be specific with no interference of mobile phase or excipients. (Fig. 2a-d). The peak purity for the standard solution and sample solution was 0.997 and 0.996 respectively (Table 3 ).

\section{Linearity}

For linearity range, correlation coefficient was 0.9998, F value was less than 0.00002 and $P$ value was 0.99999 (Fig. 3 and Table 4).

\section{Accuracy}

The method was accurate at 3 levels with \%RSD in the range of 0.02 to 0.194 (Table 5).

\section{Precision}

Repeatability and intermediate precision studies showed \%RSD, 0.272 and 0.275 respectively (Table 6).

\section{Robustness}

Change in wavelength, flow rate and column temperature caused not more than $2 \%$ difference in the assay value (Table 7).

\section{Discussion}

In HPLC, solvent under pressure moves through the stationary phase packed in the column. The components of a mixture carried by the solvent are separated from each other due to their different degrees of interaction with the stationary particles. This leads to the separation of the components as they flow out of the column and pass over the detector, where they are detected. The right choice of the stationary phase, mobile phase, detection technique, etc. can be done based on guidelines issued by regulatory agencies $[14,15]$.

Under ideal conditions, chromatographic peak has a Gaussian shape. Asymmetric peak is obtained in case of

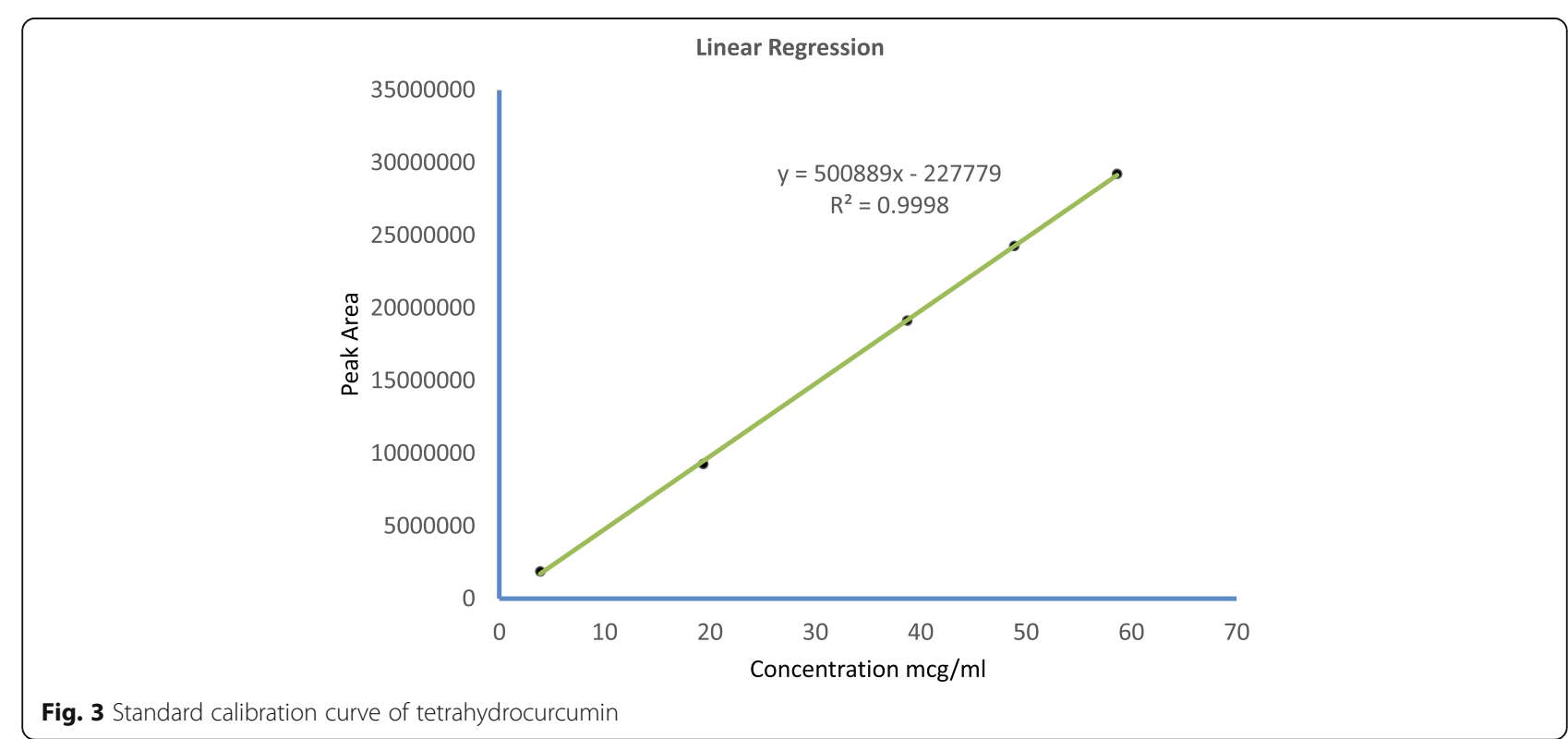


Table 4 Analysis of variance for linearity

\begin{tabular}{lllllll}
\hline $\begin{array}{l}\text { Source of } \\
\text { variation }\end{array}$ & SS & df & MS & F & $\begin{array}{l}\boldsymbol{P} \\
\text { value }\end{array}$ & F crit \\
\hline $\begin{array}{l}\text { Between } \\
\text { groups }\end{array}$ & 3421080113 & 2 & 1710540056 & $1.38172 \mathrm{E}$ & 0.99999 & 3.88529 \\
Within & $1.48557 \mathrm{E}+$ & 12 & $1.23798 \mathrm{E}+$ & & & \\
groups & 15 & & 14 & & & \\
Total & $1.48558 \mathrm{E}+$ & 14 & & & & \\
& 15 & & & & & \\
\hline
\end{tabular}

non-uniform migration and non-uniform distribution of drug in the HPLC column. Lesser the deviation, the value of asymmetry factor will be closer to 1 . The sharper the peak, the better is the column efficiency. It is measured in terms of the number of theoretical plates per column. Variation in peak area indicates nonsuitability of the method. The method showed good system suitability with an average asymmetry factor as 1.15 , \%RSD for peak area less than 2 and theoretical plates more than 5900 (Table 1). The base-deactivated silica used in the column had blocked $-\mathrm{OH}$ groups. Because of reduced silanol activity, tailing was less, and good peak symmetry was observed. THC is insoluble in water and soluble in organic solvents like alcohol and acetone. Hence, methanol was chosen as a diluent for sample preparation. THC was adequately extracted in the methanol, and excipients did not cause interference in the analysis. The mobile phase was composed of acetonitrile: methanol: water $(40: 23: 37 \% \mathrm{~V} / \mathrm{V})$, adjusted to a $\mathrm{pH}$ of $3.0 \pm 0.05$. Presence of methanol in the mobile phase ensured no plug formation after injection of sample solution. The analysis was carried out using a UV detector at a wavelength of $280 \mathrm{~nm}$ where THC showed maximum absorbance. High peak purity with no interference from solvent system or excipient indicated results specific to the THC (Fig. 2 and Table 3). The specifications for the column used in this study (i.e., C18 column, $250 \mathrm{~mm} \times 4.6 \mathrm{~mm}, 5 \mu \mathrm{m}$ ) are frequently found

Table 5 Accuracy study

\begin{tabular}{llll}
\hline Level & \% Recovery & Mean \% recovery & \%RSD \\
\hline $50 \%$ & 98.24 & 98.23 & 0.194 \\
& 98.42 & & \\
& 98.04 & & 0.016 \\
$100 \%$ & 98.31 & 98.32 & \\
& 98.32 & & \\
& 98.34 & & 0.021 \\
$150 \%$ & 100.01 & 99.99 & \\
& 99.97 & & \\
& 100.00 & & \\
\end{tabular}

Table 6 Precision study-repeatability and intermediate precision

\begin{tabular}{lll}
\hline Sample & $\begin{array}{l}\text { Repeatability } \\
\text { Peak area }\end{array}$ & $\begin{array}{l}\text { Intermediate-precision } \\
\text { Peak area }\end{array}$ \\
\hline Sample 1 & 19851008 & 19863257 \\
Sample 2 & 19848253 & 19852637 \\
Sample 3 & 19752637 & 19752634 \\
Sample 4 & 19863415 & 19752639 \\
Sample 5 & 19752635 & 19752633 \\
Sample 6 & 19863128 & 19752489 \\
Mean & $\mathbf{1 9 8 2 1 8 4 6}$ & $\mathbf{1 9 7 8 7 7 1 5}$ \\
SD & $\mathbf{5 3 9 6 2 . 9 2}$ & $\mathbf{5 4 5 0 5 . 1 9}$ \\
\%RSD & $\mathbf{0 . 2 7 2 2}$ & $\mathbf{0 . 2 7 5 4}$ \\
\hline
\end{tabular}

in columns used in laboratories and are commonly available in the market. Use of acidic $\mathrm{pH}$ for mobile phase and carefully selected composition of organic solvents ensured early elution of THC. The low retention time of 6.62 min ensured quick analysis. With short run time, more number of samples could be analyzed in the given time, making the process cost-effective. With correlation coefficient of 0.9998 , linearity between peak area and analyte concentration was evident. $F$ value lower than the $F_{\text {crit }}$ and $P>0.05$ confirmed that there is no significant difference between the slope values of the three analytical curves (Fig. 3 and Table 4). With difference less than $2 \%$, the method was found to be accurate with test results close to the true values (Table 5). The method was precise with respect to intra-day and inter-day precision (Table 6). Change in wavelength, flow rate and column temperature did not affect the analysis significantly (Table 7).

\section{Conclusion}

A new HPLC method has been developed for the identification and quantification of THC. The method has satisfactory sensitivity, specificity and repeatability. Method

Table 7 Robustness study

\begin{tabular}{|c|c|c|c|c|c|}
\hline Parameter & & RT & $\begin{array}{l}\text { Asymmetry } \\
\text { factor }\end{array}$ & $\begin{array}{l}\text { Theoretical } \\
\text { plates }\end{array}$ & $\begin{array}{l}\% \\
\text { Assay }\end{array}$ \\
\hline \multirow{2}{*}{$\begin{array}{l}\text { Change in } \\
\text { wavelength }\end{array}$} & $+3 \mathrm{~nm}$ & 6.61 & 1.15 & 5671 & 98.56 \\
\hline & $-3 n m$ & 6.62 & 1.17 & 5661 & 100.36 \\
\hline \multirow[t]{2}{*}{ Flow rate } & $\begin{array}{l}+10 \% \\
\mathrm{ml} / \mathrm{min}\end{array}$ & 6.64 & 1.18 & 5680 & 100.17 \\
\hline & $\begin{array}{l}-10 \% \\
\mathrm{ml} / \mathrm{min}\end{array}$ & 6.66 & 1.18 & 5652 & 99.09 \\
\hline \multirow{2}{*}{$\begin{array}{l}\text { Column } \\
\text { temperature }\end{array}$} & $+2^{\circ} \mathrm{C}$ & 6.56 & 1.16 & 5627 & 100.38 \\
\hline & $-2^{\circ} \mathrm{C}$ & 6.56 & 1.16 & 5641 & 100.33 \\
\hline
\end{tabular}


was successfully validated as per ICH guidelines and can be conveniently employed for routine quality control analysis of THC as bulk drug and in pharmaceutical dosage form.

\section{Abbreviations}

THC: Tetrahydrocurcumin; HPLC: High-performance liquid chromatography; UHPLC: Ultra high-performance liquid chromatography; LC-MS: Liquid chromatography-mass spectroscopy; SD: Standard deviation; RSD: Relative standard deviation; SS: Sum of squares; df: Degrees of freedom; MS: Mean sum of squares

\section{Acknowledgements}

The authors are thankful to Sami Labs, Bengaluru, Karnataka, India, for providing free sample of tetrahydrocurcumin (Sabiwhite).

\section{Authors' contributions}

RR carried out the laboratory work, collected and analyzed the data and drafted the manuscript. JS supervised the work and assisted in the data analysis. All authors read and approved the final manuscript.

\section{Funding}

Not applicable.

\section{Availability of data and materials}

All data is available upon request.

Ethics approval and consent to participate

Not applicable

\section{Consent for publication}

Not applicable

\section{Competing interests}

The authors declare that they have no competing interests.

Received: 13 September 2020 Accepted: 21 January 2021

Published online: 10 February 2021

\section{References}

1. Gupta SC, Patchva S, Koh W, Aggarwal BB (2012) Discovery of curcumin, a component of golden spice, and its miraculous biological activities. Clin Exp Pharmacol Physiol 39(3):283-299

2. Hassaninasab A, Hashimoto Y, Tomita-Yokotani K, Kobayashi M (2011) Discovery of the curcumin metabolic pathway involving a unique enzyme in an intestinal microorganism. Proc Natl Acad Sci 108(16):6615-6620

3. Okada K, Wangpoengtrakul C, Tanaka T, Toyokuni S, Uchida K, Osawa T (2001) Curcumin and especially tetrahydrocurcumin ameliorate oxidative stress-induced renal injury in mice. J Nutr 131(8):2090-2095

4. Mondal NK, Behera J, Kelly KE, George AK, Tyagi PK, Tyagi N (2019) Tetrahydrocurcumin epigenetically mitigates mitochondrial dysfunction in brain vasculature during ischemic stroke. Neurochem Int 122:120-138

5. Murugan P, Pari L, Rao CA (2008) Effect of tetrahydrocurcumin on insulin receptor status in type 2 diabetic rats: studies on insulin binding to erythrocytes. J Biosci 33(1):63-72

6. Rajeswari A, Sabesan M (2008) Inhibition of monoamine oxidase-B by the polyphenolic compound, curcumin and its metabolite tetrahydrocurcumin, in a model of Parkinson's disease induced by MPTP neurodegeneration in mice. Inflammopharmacology 16(2):96-99

7. Yoysungnoen $P$, Wirachwong $P$, Changtam $C$, Suksamrarn A, Patumraj S (2003) Anti-cancer and anti-angiogenic effects of curcumin and tetrahydrocurcumin on implanted hepatocellular carcinoma in nude mice. World J Gastroenterol 14(13):2003-2009

8. Asawanonda P, Klahan SO (2010) Tetrahydrocurcuminoid cream plus targeted narrowband UVB phototherapy for vitiligo: a preliminary randomized controlled study. Photomed Laser Surg 28(5):679-684

9. Etxabide A, Ribeiro RDC, Guerrero P, Ferreira AM, Stafford GP, Dalgarno K, de la Caba K, Gentile P, Gentile P (2018) Lactose-crosslinked fish gelatin-based porous scaffolds embedded with tetrahydrocurcumin for cartilage regeneration. Int J Biol Macromol 117:199-208
10. Setthacheewakul S, Kedjinda W, Maneenuan D, Wiwattanapatapee R (2011) Controlled release of oral tetrahydrocurcumin from a novel self-emulsifying floating drug delivery system (SEFDDS). AAPS PharmSciTech 12(1):152-164

11. Yu W, Wen D, Cai D, Zheng J, Gan H, Jiang F, Liu X, Lao B, Yu W, Guan Y, Zhong G, Zhong G (2019) Simultaneous determination of curcumin, tetrahydrocurcumin, quercetin, and paeoniflorin by UHPLC-MS/MS in rat plasma and its application to a pharmacokinetic study. J Pharm Biomed Anal 172:58-66

12. Liu A, Lou H, Zhao L, Fan P (2006) Validated LC/MS/MS assay for curcumin and tetrahydrocurcumin in rat plasma and application to pharmacokinetic study of phospholipid complex of curcumin. J Pharm Biomed Anal 40(3): 720-727

13. Heath DD, Pruitt MA, Brenner DE, Rock CL (2003) Curcumin in plasma and urine: quantitation by high-performance liquid chromatography. J Chromatogr B 783(1):287-295

14. International Conference on Harmonisation (ICH) (2005) Topic Q2 (R1): Validation of analytical procedures: text and methodology

15. Center for Drug Evaluation and Research of the Food and Drug Administration (FDA) (1994) Reviewer guidance validation of chromatographic methods.

\section{Publisher's Note}

Springer Nature remains neutral with regard to jurisdictional claims in published maps and institutional affiliations.

\section{Submit your manuscript to a SpringerOpen ${ }^{\circ}$ journal and benefit from:}

- Convenient online submission

- Rigorous peer review

- Open access: articles freely available online

High visibility within the field

- Retaining the copyright to your article

Submit your next manuscript at $>$ springeropen.com 